\title{
Ben Okri: Introduction
}

\section{Fiona McCann}

\section{(2) OpenEdition}

1 Journals

Electronic version

URL: https://journals.openedition.org/ces/5312

DOI: $10.4000 /$ ces. 5312

ISSN: 2534-6695

\section{Publisher}

SEPC (Société d'études des pays du Commonwealth)

\section{Printed version}

Date of publication: 1 April 2013

Number of pages: 5-8

ISSN: 2270-0633

\section{Electronic reference}

Fiona McCann, "Ben Okri: Introduction", Commonwealth Essays and Studies [Online], 35.2 | 2013, Online since 17 April 2021, connection on 23 July 2021. URL: http://journals.openedition.org/ces/5312 ; DOI: https://doi.org/10.4000/ces.5312

\section{(c) (i) (5) $\Theta$}

Commonwealth Essays and Studies is licensed under a Licence Creative Commons Attribution - Pas d'Utilisation Commerciale - Pas de Modification 4.0 International. 


\section{Introduction}

The universities of the future will do one thing we do not do today. They will teach the art of self-discovery. There is nothing more fundamental in education.

We turn out students from our universities who know how to give answers, but not how to ask the essential questions.

\section{Ben Okri, "Plato's Dream,"} A Time for New Dreams, 27

Yesterday's road has led

To yesterday's destination.

Today is a new chaos.

A new journey. A new city.

Needing new paths. And new standards.

Ben Okri, "The Ruin and the Forest," Wild, 45

This issue of Commonwealth Essays and Studies has its genesis in the inclusion of Ben Okri's award-winning The Famished Road on the 2013 syllabus for the prestigious French teaching examination, the Agrégation. The Agrégation is not simply a demanding competition aimed at recruiting the very best students in English as teachers; it often sows the seeds of future research projects, with students being exposed to literatures and socio-historical questions they may not have come across before and new affinities emerging as a result. There can be no doubt then that the choice of a major novel by one of Africa's most innovative and prolific authors is a strong acknowledgement of the significance of African literature in English and perhaps a tacit means of signposting new directions in research for students.

In one sense, one might say that The Famished Road is a perfect text for this particular examination as the intensive preparation involved actually invites students to take on board Ben Okri's own vision, expressed in the above epigraph and, arguably, in The Famished Road itself, of what learning should encompass: not just knowing "how to give answers" but also, perhaps more importantly, knowing "how to ask the essential questions." The reader of The Famished Road is inevitably pushed out of her comfort zone and driven by its very complexity to actively participate in the reading experience, as opposed to passively, unquestioningly, receiving the text. Our initial sense of disorientation as Azaro moves or perceives others moving from the earthly, material world to the spirit world and back again gradually morphs into a unique reading experience in which the constant flowing and changing within the narrative incessantly alerts us to the necessity of simultaneously allowing ourselves to be carried away by the "flow of life," perceiving the novel as a "tidal wave" of sorts, with water beating, lapping and retreating (Wilkinson 83), and obliging ourselves to construct meaning from the apparent disorder. 
The second epigraph is taken from a poem included in Okri's most recent collection, Wild (2012) in which a clear opposition is established between "chaos" and "order" ("The Ruin and the Forest" 44). In typical Okrian style, however, chaos and order are not exclusively associated with either "them" or "us"; rather they are presented as coexisting and inter-related as the binaries the poem at first seems to uphold are gradually dissolved. Any attempt to pigeonhole either "them" or "us" is doomed to failure since, as The Famished Road illustrates so well, Okri does not deal in Manichean oppositions. At the risk of leading us, like Azaro, into a "rich forest of misunderstandings," ("The Ruin" 45) Okri nevertheless invites us to bear in mind the necessity of constantly searching out new paths of creative expression in order to represent our ever-changing world. The etymology of "chaos" is the Greek khaos meaning "abyss," that which gapes wide open, vast and empty, yet The Famished Road is anything but a void; on the contrary, teeming with perceptions, actions, experiences and dreams, all of which are rendered in complex poetic prose, the novel literally overflows precisely in an attempt to counter chaos.

Numerous essays, articles and monographs have of course been devoted to Ben Okri and his work, many of which focus on The Famished Road trilogy. Ever since the publication of The Famished Road in 1991 and the subsequent Booker Prize award, Okri's work has garnered significant critical attention and the author has carved out a very specific place for himself in the contemporary literary landscape. Various critics have honed in on the postcolonial and postmodern dimensions of his fiction and poetry, Olatobosun Ogunsanwo stating that "Okri has indeed achieved this combination of distinct Western and African literary modes, and in postmodernist fashion" (43). And yet the absence of consensus on Okri's work, including the possibility of exploring it through the prism of postcolonial or postmodern theory, speaks volumes about its diversity and originality, the "new standards" it sets, to use the poet's own words. This collection of essays seeks to expand upon the wealth of existing criticism, offering new and innovative readings by both early career researchers and prominent critics in the field. These investigations focus on this novel in its own right as well as on its relation to Okri's literary forefathers and contemporaries and the rest of Okri's work. Taking heed of Okri's exhortation to embark upon "a new journey" which requires "new paths," the essays included in this volume navigate a "new road" ("The Ruin" 45) encompassing socio-political and literary contextualisation, close readings, and broader consideration of Okri's work as a whole.

The first two articles provide a rich contextualisation of The Famished Road, both in terms of its position in post-War West African literature in English and of a discussion of the place and type of spiritualities displayed in the novel. Philip Whyte investigates the significant change in Okri's aesthetics in The Famished Road, read against the backdrop of his first two novels. He also reveals how, despite this stylistic evolution, the novel simultaneously displays elements which clearly anchor it in a tradition of West African writing and offers evidence of a new departure which provides fertile possibilities for literary exploration. These avenues are explored within an overarching analysis of what Whyte terms "the increasingly problematic field of so-called postcolonial literature and theory in the 1990s." Douglas McCabe's article provides a very different sort of contextualisation, taking as a point of departure the convergence in the novel of Western New Age and indigenous spiritualities. Carefully anchoring Okri's abiku novel 
within a long discursive tradition in which the abiku is associated with hunger, he moves beyond the obvious recognition of Soyinka's influence, and analyses Okri's exploration of a New Age spirituality. Furthermore, through a study of the double biblical allusion in Azaro's name, McCabe suggests that although Okri rescues the trope of the famished abiku from its roots in "colonialist evolutionism" and redeploys it within a New Age framework, he also potentially perpetuates these same colonialist representations because of his very reliance on them.

The two following articles propose an analysis of The Famished Road in conjunction with a reading of other fictional works published after the award-winning novel. Christopher Ringrose pursues the discussion of spiritualities in Okri's fiction by considering the intersection of spiritual and material journeys in the novel and the ways in which these itineraries are revealing of specific social conditions. Reading The Famished Road against the backdrop of later novels such as Dangerous Love, Astonishing the Gods and In Arcadia, Ringrose suggests that Okri is a "transnational writer" as Andreas Huyssen defines it, transcending the local/global dichotomy and reflecting on how spirituality can manifest itself in a corrupt world which disempowers the poor. Elizabeth Syrkin's article complements the previous one by focusing on what she terms "trans-realism" in Okri's Astonishing the Gods and The Famished Road and analysing how these novels transcend the rigid categories into which Okri's novels are sometimes pushed. Syrkin goes on to show how Okri's novels stage a dialogue between political realities and adequate aesthetic responses to them.

Catherine Lanone explores The Famished Road through the prism of Michel Serres's analysis of "the paradigm of the parasite" and provides a reading which investigates its thematic and formal dimensions in the novel. For Lanone, the episodic, repetitive structure of the text, which can be seen as a sort of "parasitic interference," reflects the dynamics of parasitic transformation explored in relation to the political situation with both negative and positive outcomes in the novel. Mélanie Joseph-Vilain's article analyses Okri's novel as an avatar of the "family romance" as Freud terms the stories children tell themselves in order to make sense of their origins. Focusing in particular on storytelling practices in the novel, Joseph-Vilain demonstrates how Okri not only inserts Azaro into a genealogy, but also reinvents himself as a writer, "redreaming the novel" just as Dad "redream[s] the world."

The three following articles all discuss different facets of the intriguing narrative style of The Famished Road. Vanessa Guignery suggests we read the novel as a "simulacrum of a symphony" and analyses the paradox of Okri's exploration of the poetics of voice, in which the demands of the indigenous oral folktale and the written text are potentially reconciled. The "sonorous tableau" which results, argues Guignery, enables Okri to probe the politics of representation and power relations and to invite us to "read with [our] ears." Kerry-Jane Wallart's article complements Guignery's by returning to and extending a commonplace in criticism of The Famished Road: that of the ambivalence of a narrator who enjoys an omniscience of sorts yet whose perspective remains highly limited. Arguing that fiction ultimately turns out to be irrelevant in the face of poverty and corruption, she nevertheless shows that the novel is not to be read reductively as a lament, but rather as a catalyst for vigorous change. Wallart concludes her article by intimating that fiction "helps to formulate the most adequate interrogations," thus bringing us back to Okri's own conviction quoted in the first epigraph that 
students (and, by extension, all of us) should be encouraged to "ask the essential questions." Kathie Birat also tackles what she calls "the paradoxes of narration" in the novel, suggesting that it should be viewed through multiple cultural and generic frames if one is to have any hope of fully understanding Okri's aesthetics. She contends that the reader of The Famished Road must accept the paradoxical relationship between, on the one hand, "the constraints of fiction" and, on the other, "the unlimited nature of reality."

Published in the same year which saw the passing away of fellow countryman and prolific author Chinua Achebe, it is hoped that these articles on Okri's fictional works contribute to a much wider acknowledgement of, in the words of Wole Soyinka and JP Clark, both authors' "enduring testimony to the domination of the human spirit over the forces of repression, bigotry and retrogression" (Soyinka and Clark n.p.).

Fiona McCann, Guest Editor

\section{Works Cited}

Okri, Ben. Wild. London: Rider, 2012.

- A Time for New Dreams. London: Rider, 2011.

Ogunsanwo, Olatobosun. "Intertextuality and Post-Colonial Literature in Ben Okri's The Famished Road." Research in African Literatures 26.1 (Spring 1995): 40-52.

SOYINKA, Wole, and JP CLARK. "Chinua Achebe's death: we have lost a brother." The Guardian 22 March 2013. <http://www.guardian.co.uk/commentisfree/2013/mar/22/chinua-achebe-wole-soyinkajp-clark> Accessed 2 May 2013.

Wilkinson, Jane. "Ben Okri." Talking with African Writers. London/Portsmouth: James Currey/ Heinemann, 1992. 76-89. 